\title{
AC 2008-2874: ENGINEERING CAREERS: A DAY FOR YOUNG WOMEN
}

\section{Brenda Hart, University of Louisville}

Director of Student Affairs at the J.B. Speed School of Engineering. Her research interests include recruitment and retention programs for females and under-represented minorities as well as activities for first year engineering students.

\section{Veronica Hinton-Hudson, University of Louisville}

Currently an Assistant Professor in the Computer Information Systems Department within the College of Business. Her research interests include Quality Engineering and applied statistics, Production Operations, Systems Analysis, mentoring, and STEM pre-college initiatives and programs. 


\title{
ENGINEERING CAREERS: A DAY FOR YOUNG WOMEN
}

\begin{abstract}
As the need for engineering professionals in the United States continues to grow, the severity of the under-representation of women in the profession is further magnified. This is true whether or not the engineers are practicing their profession, are educators in the field, or both. This employment shortage is a national problem that must be addressed in a more strategically focused manner. ${ }^{[1]}$ Exposing more young women to the various careers in engineering is an important step to recruiting more females into this field. This paper presents a program that specifically focuses on the identification and recruitment of high school young women to engineering, with specific attention to the offerings at the University of Louisville J.B. Speed School of Engineering.
\end{abstract}

\section{Introduction}

Women and minorities have been underrepresented by alarming proportions in institutions of higher education in general and in science and engineering (S\&E) programs in particular over the last quarter century. Although more female and minority high school students have at least heard of engineering, relatively few of them have had the opportunity to become familiar with engineers and the work they perform. As noted in Figure 1, Bachelor's degrees awarded in S\&E and non-S\&E fields by sex for the years of 1966-2004, nationally, women earn substantially more bachelor's degrees in non-S\&E fields than men.

\section{Program background}

The University of Louisville J.B. Speed School of Engineering offers seven engineering degree options. In 1995, personnel from the University of Louisville School of Engineering were concerned with the decrease in the numbers of young women entering the engineering programs especially given that nationally the number of S\&E bachelor's degrees awarded to women had increased every year since 1966 (excluding 1988). ${ }^{[2]}$ Taking into consideration the costs and time constraints presented, it was decided to develop and implement a Women's Career Day, sponsored by the Speed School of Engineering. Local high school female students to would be invited to spend a day on the university's main campus in the School of Engineering. The program would be designed with the following goals in mind:

1. to introduce young women to the field of engineering and to thus encourage them to continue their pursuit of advanced math and science courses

2. to provide female role models to the program participants by including panels of both female engineering students and female professional engineers as discussants. 
3. to provide high school teachers and counselors with additional information about the admissions process, financial aid, and cooperative education opportunities at the University of Louisville, particularly in engineering.

4. to encourage enrollment of young women in STEM fields (principally within an engineering discipline) with hopes that many of the participants would elect to attend the University of Louisville, as their post-secondary institution choice.

More than $52 \%$ of the University's total undergraduate enrollment is female. However, the undergraduate engineering enrollment for fall, 2007 was 1,293 students and only 218 were female (16.86\%). Figure 2 shows that from 1995 through 2005, the University has been below the national average for full-time, first-year female enrollments in engineering. ${ }^{[3]}$ For more than 10 years, the University of Louisville has conducted an Engineering Career Day program for young women from the surrounding community. Its primary purpose has been to introduce engineering as a viable career option to young women from Louisville area public and parochial schools. This research discusses this particular recruitment strategy, program activities, costs and overall outcomes of this program. The remainder of this paper details the program as a model for other engineering schools seeking a low-cost outreach pre-college engineering program for identifying and recruiting young women.

\section{Participants and program}

Applications and letters are sent to area high school counselors, math/science department chairs and to young women who have applied to the Speed School of Engineering. Although most of the program participants are sophomores or juniors in high school, some of them are high school seniors who have already admitted to the University. Some of these young women may have also been admitted to other universities. Participation in the Career Day gives these students additional exposure to the University of Louisville and thus may enhance our success in attracting them to our institution.

Career Day is from 9AM to 3:00PM and is held on the University of Louisville campus. Table 1 outlines the content of the elements of the 1-day program. The lab demonstrations take place between 12:30 - 2:10PM. This part of the program allows the participants to interact with engineering faculty members and graduate students and introduces them to engineering concepts. For example, the faculty member overseeing the session on mechanical engineering demonstrated a small wind tunnel. These devices are used in industry to measure forces that air flow exerts on cars, aircraft and on athletes such as skiers and cyclists. The faculty member described some of the features of wind tunnels and the force measurement system. Two simple shapes were put into the wind tunnel and the group measured the lift force and drag force on these objects.

The session on computer science and engineering provided the students with information about contributions women have made to the history of computing. It also included a robot demo movie and then the students were split into teams to solve a heavy coin 
puzzle. One of the faculty members in that session gave a demonstration about car traffic simulation and showed the power of modeling and termites by illustrating swarms. He showed how these related to actual life problems by explaining how swarms of robots could be used to clean out hazardous materials.

In early years the programs were held each fall and spring semesters of the academic year. In order to accommodate numbers in the labs and allow for optimal personal interaction, participation is capped at 30 attendees each program. However, registration for the fall programs was small and for two years in a row the numbers were so low that the program had to be cancelled. Because of that, the decision was made to hold the Career Days just once a year. For the past four years the Career Days have only been conducted during the spring terms, usually in February or early March, and response has been very positive. Transportation to and from campus is arranged by the participants. Maps and parking permits are provided. The only cost to the participants is $\$ 5$ each which helps defray the cost of putting on the program. Table 2 provides an estimated budget for each 1-day occurrence of the program.

While the Career Day focuses primarily on the high school students, teachers and counselors are also invited to participate. Occasionally, parents of the high school students have also asked to participate and they have been allowed to attend.

\section{Outcomes}

Career Day programs have been conducted on the University of Louisville J.B. Speed School of Engineering campus since 1995. Personnel are in the process of developing a data base of past student participants. Once that has been created, personnel from the University's Office of Institutional Research will be able to "track" the students who have entered the University of Louisville and thus determine how many students completed degrees and in which fields.

A few years ago a survey form was developed and mailed out to former student participants. The intent was to "track" the students to see which colleges they applied to, where they actually enrolled, the student's intended major of study and actual major upon degree completion. The survey also asked to what extent participation at the Career Day contributed to the student's college major. Although few surveys were returned, plans are still underway to try to contact former participants in order to secure this valuable "tracking"data.

Given the enthusiasm expressed by the students at the end of each day, University of Louisville personnel contend that Career Day is highly successful. At the completion of the program, each participant is asked to complete a brief evaluation form. Comments are routinely very positive and the students always rate the program as "very successful" The following responses are representative feedback from program participants when asked the question, "Did attending Career Day change your idea about what career you might choose in the future?" 
"I had no idea what engineers did and this sparked an interest in electrical engineering."

"I did not realize that I was interested in other types of engineering."

"I have had only one goal for the past year, to be a radiologist. This program has changed my mind".

"I am so motivated and inspired now to pursue college and am looking into engineering programs. This program was worthy of 500+ students!

Thanks!!"

Several students have commented to the program director, who also serves as faculty advisor to the school's chapter of the Society of Women Engineers (SWE), that their decision to enroll at the Speed School was made after they participated in the Career Day. These students also eagerly serve as volunteers to help with upcoming Career Days and ask to be on the student panel.

\section{Conclusion}

Participants are able to hear "real life" experiences from female engineering students as well as from practicing female engineers. Questions during the panel sessions range from suggested high school courses to enroll in to managing family related issues. The program participants actively participate in three engineering lab demonstrations conducted by the university engineering faculty members or their graduate students. Meeting other female high school students with similar career interests as themselves from other area high schools is also of value to program participants.

In summary, this paper has presented the model of a low cost, one day, outreach program that targets high school young women. This program continues to focus on its goals of (1) introducing young women to the field of engineering and encouraging them to enroll in more advanced math and science courses; (2) providing an opportunity to interact with other female engineering role models; (3) providing high school teachers and counselors with additional pertinent university enrollment information for both program participants and non-participants; and (4) providing encouragement to enroll in a STEM career field, preferably at the University of Louisville. Further research methods are encouraged to improve the traceability process for these pre-college students once they have graduated from high school. This program can be easily adapted to other university settings and can help identify and recruit additional female students into the field of engineering. 
Figure 1. S\&E versus non-S\&E Awarded Degrees by gender: 1966-2004

\section{Bachelor's degrees awarded in S\&E and non-S\&E fields, by sex: 1966-2004}

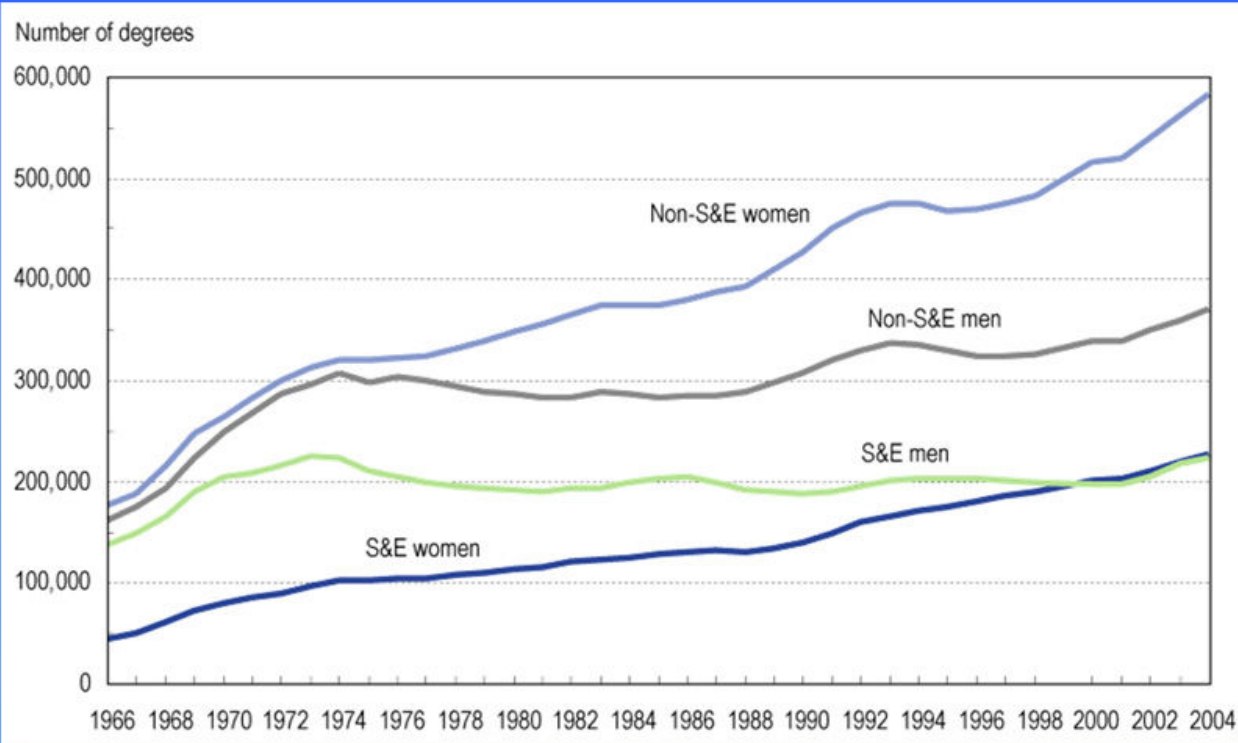

SOURCE: Women, Minorities and Persons With Disabilities in Science and Engineering (December 2006

SOURCE: National Science Foundation, Division of Science Resources Statistics, special tabulations of U.S. Department of Education, National Center for Education Statistics, Integrated Postsecondary Education Data System, Completions Survey, 1966-2004. 
Figure 2 National versus University of Louisville Full-Time, First-Year Undergraduate Females in Engineering: 1995-2005

National vs Our University Trend for Full-Time First-Year Undergraduate Female Students: 1995-2005

- National Female - - - Our University Female

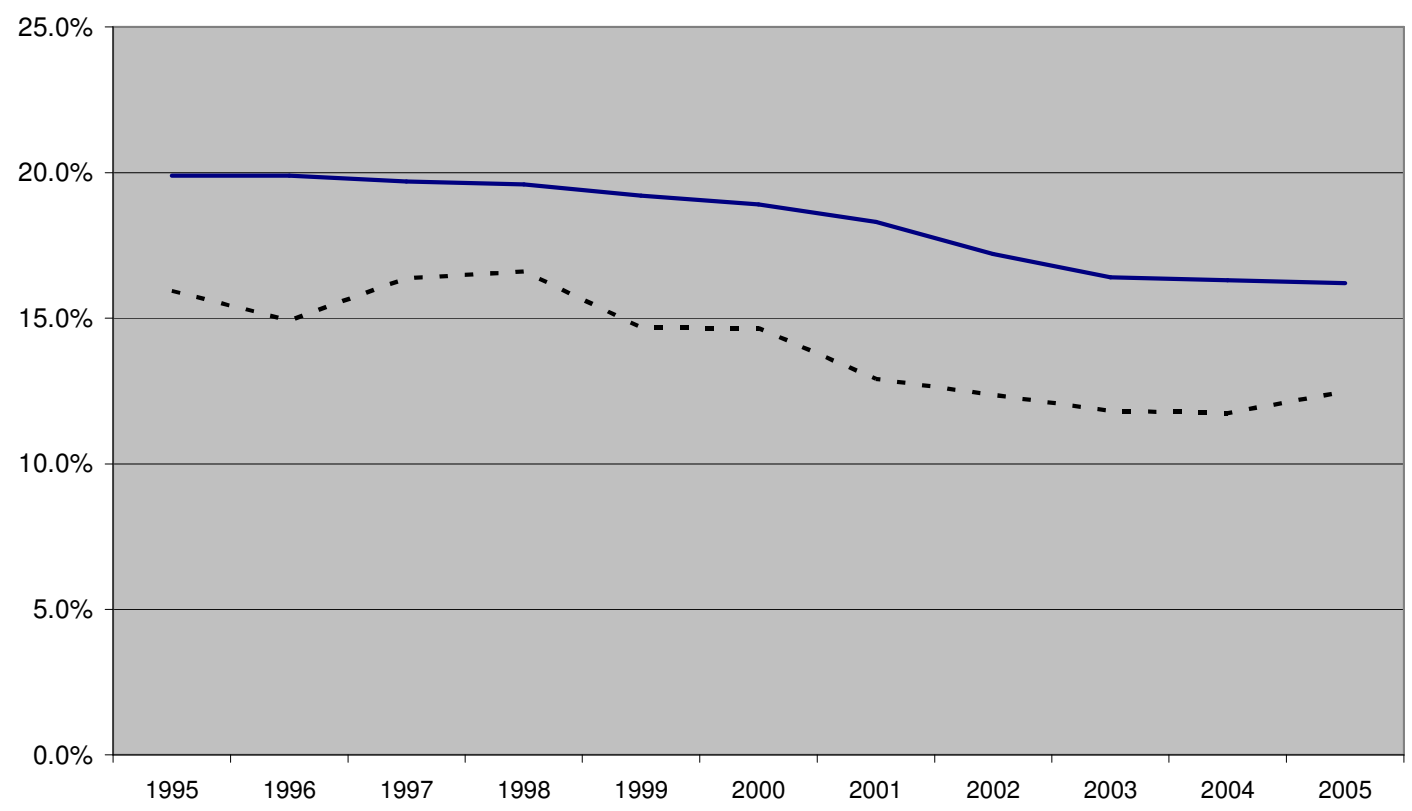


Table 1. Typical 1-Day Schedule for Career Day

$\begin{array}{ll}\text { 9:00-9:15AM } & \text { Registration and refreshments } \\ \text { 9:15-9:25AM } & \text { Welcoming remarks } \\ \text { 9:25 - 9:45AM } & \text { Introduction to the J.B. Speed School of Engineering } \\ \text { 9:45-10AM } & \text { Admissions process, financial aid, course selection } \\ \text { 10:00-10:10 } & \text { Break } \\ \text { 10:10-11AM } & \text { Student panel (composed of engineering students) } \\ \text { 11:00-11:50 } & \text { Panel of female engineers } \\ 11: 50-12: 20 \mathrm{PM} & \text { Lunch (Panel discussants are invited to join the young ladies) } \\ 12: 30-2: 10 \mathrm{PM} & \text { Demonstrations in engineering labs (choice of 3 departments) } \\ 2: 10-2: 25 \mathrm{PM} & \text { Wrap up and program assessment } \\ 2: 25-3 \mathrm{PM} & \text { Campus tour (optional) }\end{array}$


Table 2. Program Estimated Costs

\begin{tabular}{lc}
\hline \multicolumn{1}{c}{ Item } & Cost \\
Continental breakfast ( $\$ 4.50$ per person) & $\$ 135$ \\
Box lunches ( $\$ 8$ per person) & 240 \\
Folders & 30 \\
Token gifts for panel members $(\$ 5$ per person) & 40 \\
Miscellaneous (postage, copying, etc.) & 25 \\
& 470 \\
Total & $470-$ thus overall cost is \\
(Minus participants' contribution/charge of $\$ 5$ per person - $\$ 150$ - &
\end{tabular}




\section{References}

${ }^{1}$ Chubin, D.E., G.S. May, and E.L. Babco, Diversifying the Engineering Workforce. Journal of Engineering Education, 2005. 94(1): p. 73-86.

${ }^{2}$ National Science Foundation, Completions Survey 1966-2004, special tabulations of U.S. Department of Education. 2006, National Center for Education Statistics, Integrated Postsecondary Education Data System.

${ }^{3}$ Engineering Workforce Commission, Engineering \& Technology Enrollments: Fall 2005 2006, Washington, DC.

BRENDA G. HART is Director of Student Affairs at the J.B. Speed School of Engineering. Her research interests include recruitment and retention programs for females and under-represented minorities as well as activities for first year engineering students.

VERONICA HINTON-HUDSON is currently an Assistant Professor in the Computer Information Systems Department within the College of Business. Her research interests include Quality Engineering and applied statistics, Production Operations, Systems Analysis, mentoring, and STEM pre-college initiatives and programs. 